\title{
Pengaruh Model Discovery Learning Berbantuan Multimedia Interaktif Terhadap Kemampuan Berpikir Kritis Siswa di SMPN 2 Poigar
}

\author{
Tirsa Regina Potu1 ${ }^{*}$, Cosmas Poluakan ${ }^{2}$ \\ ${ }^{1}$ Jurusan Pendidikan IPA, FMIPA, Universitas Negeri Manado \\ 2Jurusan Pendidikan Fisika, FMIPA, Universitas Negeri Manado \\ *e-mail: tirsareginapotu@gmail.com
}

\begin{abstract}
Abstrak. Penelitian ini bertujuan mengetahui pengaruh model discovery learning berbantuan multimedia interaktif terhadap kemampuan berpikir kritis siswa. Metodologi penelitian yang digunakan adalah nonequivalent control group design. Populasi dalam penelitian ini adalah seluruh siswa kelas VIII SMPN 2 Poigar, yang terdiri dari dua kelas yakni kelas A sebanyak 30 siswa sebagai kelas eksperimen dan kelas B sebanyak 30 siswa sebagai kelas kontrol. Hasil analisis data diperoleh dari nilai pretest dan posttest yang diuji menggunakan SPSS. Hasil penelitian menunjukan bahwa model discovery learning berbantuan multimedia interaktif terhadap kemampuan berpikir kritis siswa di SMPN 2 Poigar mempunyai pengaruh yang signifikan, dengan nilai Sig. a sebesar 0,000<0,05. Oleh karena nilai Sig. a sebesar 0,000 lebih kecil dari 0,05 maka dapat disimpulkan bahwa terdapat pengaruh model discovery learning berbantuan multimedia interaktif terhadap kemampuan berpikir kritis siswa di SMPN 2 Poigar.
\end{abstract}

Kata kunci: discovery learning, berpikir kritis

\begin{abstract}
This study aims to determine the effect of interactive multimedia-assisted discovery learning models on students' critical thinking skills. The research methodology used was the nonequivalent control group design. The population in this study were all students of class VIII SMPN 2 Poigar, which consisted of two classes, namely class A with 30 students as the experimental class and class $B$ with 30 students as the control class. The results of data analysis were obtained from the pretest and posttest values tested using SPSS. The results showed that the interactive multimedia-assisted discovery learning model on students' critical thinking skills at SMPN 2 Poigar had a significant effect, with a Sig. a is $0.000<0.05$. Hence the Sig. a of 0.000 is smaller than 0.05, so it can be concluded that there is an effect of the discovery learning model assisted by interactive multimedia on the critical thinking skills of students at SMPN 2 Poigar.
\end{abstract}

Keywords: discovery learning, critical thinking

Diterima 21 November 2020 | Disetujui 29 Desember 2020 | Diterbitkan 31 Desember 2020

\section{PENDAHULUAN}

Upaya peningkatan kualitas pendidikan dapat tercapai secara optimal, apabila dilakukan pengembangan dan perbaikan terhadap komponen pendidikan. Komponen pembelajaran meliputi tujuan pendidikan, peserta didik, pendidik, bahan atau materi pelajaran, pendekatan dan metode, media atau alat sumber belajar, evaluasi.
Komponen pendidikan adalah bagianbagian dari sistem proses pendidikan yang menentukan berhasil atau tidaknya proses pendidikan (Slameto, 2010).

Pesatnya era globalisasi dan perkembangan IPTEK khususnya pada teknologi komunikasi menuntut bangsa Indonesia memiliki daya saing dan keunggulan kompetitif, hal ini karena era globalisasi menjadi tantangan yang 
terkait dengan daya saing manusia untuk berpikir tingkat tinggi yang mencakup didalamnya yaitu kemampuan berpikir kritis (Sadia, 2014).

Berpikir kritis adalah sesuatu yang digunakan dalam kegiatan sehari-hari dalam memecahkan berbagai masalah. (Agoestanto \& Sukestiyarno, 2017). Berpikir kritis memungkinkan seseorang untuk menganalisis, mengevaluasi, menjelaskan dan mengatur kembali pemikirannya sehingga mengurangi resiko kesalahan dalam mengambil suatu keputusan dalam menghadapi masalah yang sering terjadi dalam kehidupan (Adeyemi, 2012).

Guru sebagai pilar utama pendidikan, perlu melakukan perubahan dalam sistem pembelajaran (Hudha \& Batlolona, 2017). Objek yang paling sering digunakan dalam dunia pendidikan adalah multimedia, yaitu integrasi teks, audio, video, grafik dan animasi ke dalam satu media. Multimedia pembelajaran merupakan integrasi dari berbagai bentuk media dalam proses pembelajaran (Siregar, Sutopo \& Paat, 2019).

Multimedia digunakan dalam pendidikan, yaitu integrasi teks, audio, video, grafik dan animasi menjadi satu media. Multimedia pembelajaran mengintegrasikan berbagai jenis media di proses pembelajaran (Paat, Sutopo \& Siregar, 2019).

Umumnya dalam proses mengajar guru ditutut untuk mewujudkan dan menciptakan situasi yang memungkinkan siswa aktif dan kreatif, namun kenyataannya masih banyak guru dalam proses pembelajar banyak terpusat pada guru atau dikenal dengan istilah teacher center (pusat guru) dibandingkan dengan student center (pusat siswa), sehingga sumber informasi pembelajaran hanya di peroleh dari guru saja. Siswa tampak kurang aktif dan pembelajaran yang diperoleh siswa kurang efektif jika dibandingkan dengan student center (Guntur, Eka \& Titin, 2014).

Terkait dengan keberhasilan siswa dalam belajar tidak terlepas peran aktif guru yang mampu memberi motivasi dan dapat menciptakan pengaruh belajar yang harmonis, kondusif, menyenangkan, dan mampu memberi semangat kepada siswa. Rendahnya berpikir kritis siswa dipengaruhi oleh beberapa faktor, baik faktor internal maupun faktor eksternal. Yang termasuk faktor internal adalah faktor jasmani dan psikologis misalnya kesehatan, kecerdasan, motivasi berprestasi dan kemampuan (kognitif), sedangkan yang termasuk eksternal adalah faktor keluarga, faktor sekolah, faktor masyarakat misalnya guru, kurikulum dan model pembelajaran (Slameto, 2010).

Berdasarkan observasi yang dilakukan di SMPN 2 Poigar, diperoleh informasi bahwa kreatifitas guru belum terasah dengan baik, sehingga proses pembelajaran tidak bervariasi, dalam hal ini siswa sulit mengembangkan kemampuan berpikir kritisnya khususnya pada materi sistem pernapasan manusia. Sehingga perlu dicari alternatif lain agar proses pembelajaran dapat berlangsung aktif dan mampu meningkatkan berpikir kritis siswa. Salah satu model pembelajaran yang dapat membuat siswa lebih aktif mengeluarkan pendapat dan menemukan konsepnya sendiri adalah model discovery learning berbantuan multimedia interaktif. Discovery learning adalah suatu model untuk mengembangkan cara belajar aktif dengan menemukan sendiri, menyelidiki sendiri, maka hasil yang diperoleh akan setia dan tahan lama dalam ingatan (Hosnan, 2014).

Penelitian ini bertujuan untuk mengetahui pengaruh model discovery learning berbantuan multimedia interaktif terhadap kemampuan berpikir kritis siswa di SMPN 2 Poigar.

\section{METODE PENELITIAN}

Penelitian ini dilaksanakan di SMPN 2 Poigar semester genap 2019/2020. Metode penelitian yang digunakan adalah penelitian yang mengacu pada quasi experimental design atau eksperimen semu, dalam bentuk nonequivalent control group design. Terdapat kelas eksperimen dan kelas kontrol, dimana pengambilan sampelnya dilakukan secara eksperimen (Sugiyono, 
2015). Adapun desain penelitian ini dapat dilihat pada Tabel 1.

Tabel 1. Rancangan penelitian

\begin{tabular}{lll}
\hline Pretest & Perlakuan & Posttest \\
\hline $\mathrm{O}_{1}$ & $\mathrm{X}$ & $\mathrm{O}_{2}$ \\
$\mathrm{O}_{3}$ & - & $\mathrm{O}_{4}$ \\
\hline
\end{tabular}

Keterangan

$\mathrm{O}_{1}$ : pretest untuk kelas eksperimen

$\mathrm{O}_{2}$ : postest untuk kelas eksperimen

$\mathrm{O}_{3}$ : pretest untuk kelas kontrol

$\mathrm{O}_{4}$ : posttest untuk kelas kontrol

$\mathrm{X}$ : perlakuan model discovery learning

berbantuan multimedia interaktif

Populasi dalam penelitian ini adalah seluruh siswa kelas VIII SMPN 2 Poigar. Sampel dalam penelitian ini yaitu kelas VIII-A yang terdiri dari 30 siswa sebagai kelas eksperimen yang menggunakan model discovery learning berbantuan multimedia interaktif dan kelas VIII-B yang terdiri dari 30 siswa sebagai kelas kontrol yang menggunakan pembelajaran konvensional.

Teknik pengumpulan data yaitu dalam bentuk tes. Tes yang digunakan dalam penelitian ini terdiri dari item-item yang dijawab dengan memilih satu opsi jawaban yang benar dari lima opsi yang tersedia. Tes ini terdiri dari 10 soal yang diambil dari buku pelajaran IPA, dimana setiap soal yang dijawab nilainya sesuai dengan tingkat kesulitannya misalnya soal nomor 1 bobot nilainya adalah 10 apabila tidak menjawab berarti skornya 0 , jadi skor yang tertinggi tiap soalnya adalah tergantung pada nilai bobot soal tersebut. Sebelum digunakan, instrument ini diuji validitas dan reliabilitasnya.

Teknik analisis data dilakukan sebelum menguji suatu hipotesis penelitian, dilakukan terlebih dahulu uji prasyarat, dalam hal ini uji normalitas data dan uji homogenitas data.

Uji hipotesis dilakukan setelah dilakukan uji prasyarat untuk melihat perbandingan variabel dari rata-rata kedua sampel (Riduwan, 2015).

Dalam penelitian ini, uji hipotesis menggunakan software SPSS 22 dengan uji independent sample t-test yang bertujuan untuk menguji beda rata-rata dua kelompok dan untuk menguji pengaruh variabel independen terhadap variabel dependen (Trihendradi, 2010).

Adapun langkah-langkahnya adalah sebagai berikut: (1) input data pada data view; (2) analyze; (3) compare means; (4) independent sample t-test (Riadi, 2016). Dengan kriteria pengujian

$$
\begin{aligned}
& \mathrm{H}_{0}=\mu_{0}<\mu_{1} \\
& \mathrm{H}_{1}=\mu_{0}>\mu_{1}
\end{aligned}
$$

Pengujian dilakukan dengan mengajukan hipotesis penelitian sebagai berikut:

$\mathrm{H}_{0}$ : tidak terdapat pengaruh model discovery learning berbantuan multimedia interaktif terhadap kemampuan berpikir kritis siswa materi sistem pernapasan manusia.

$\mathrm{H}_{1}$ : terdapat pengaruh model discovery learning berbantuan multimedia interaktif terhadap kemampuan berpikir kritis siswa.

Dengan kriteria, jika sig $>a(0,05)$, maka $\mathrm{H}_{0}$ diterima, $\mathrm{H}_{1}$ ditolak; jika sig $<a$ $(0,05)$, maka $\mathrm{H}_{0}$ ditolak, $\mathrm{H}_{1}$ diterima.

\section{HASIL DAN PEMBAHASAN}

Berdasarkan penelitian yang telah dilakukan, diperoleh data hasil pretest dan posttest pada kelas kontrol dan eksperimen. Data tersebut diperoleh dengan menggunakan instrumen tes sebanyak 10 soal. Data hasil prestest dan posttest pada kelas kontrol dan eksperimen berdasarkan indikator berpikir kritis, dapat dilihat pada Tabel 2 .

Tabel 2. Data hasil prestest dan posttest pada kelas kontrol dan eksperimen berdasarkan indikator berpikir kritis

\begin{tabular}{lllll}
\hline \multirow{2}{*}{ Data } & \multicolumn{3}{c}{ Pretest } & \multicolumn{2}{c}{ Posttest } \\
\cline { 2 - 5 } & Kontr & $\begin{array}{l}\text { Ekspe } \\
\text { rimen }\end{array}$ & $\begin{array}{l}\text { Kontr } \\
\text { ol }\end{array}$ & $\begin{array}{l}\text { Ekspe } \\
\text { rimen }\end{array}$ \\
\hline $\begin{array}{l}\text { Jumlah } \\
\text { siswa }\end{array}$ & 30 & 30 & 30 & 30 \\
$\begin{array}{l}\text { Nilai } \\
\text { tertinggi }\end{array}$ & 57,5 & 50 & 85 & 92,5 \\
$\begin{array}{l}\text { Nilai } \\
\text { terrendah }\end{array}$ & 20 & 20 & 60 & 67,5 \\
Rata-rata & 40,08 & 37,83 & 73,25 & 82,83 \\
\hline
\end{tabular}

Berdasarkan hasil uji normalitas dan homogenitas diperoleh data pretest dan posttest di kelas eksperimen dan 
kontrol, masing-masing berdistribusi normal dan data pretest dan posttest dari kedua kelas adalah homogen.

Pengujian normalitas dan homogenitas sudah memenuhi uji prasyarat analisis, selanjutnya dilakukan uji hipotesis mengunakan rumus uji t, yang hasilnya dapat dilihat pada Tabel 3.

Tabel 3. Hasil uji t

\begin{tabular}{|c|c|c|}
\hline \multicolumn{2}{|c|}{ Statistik } & Kesimpulan \\
\hline$a$ & 0,05 & Sig $>a$ \\
\hline Sig. & 0,284 & $\begin{array}{l}\text { (tidak terdapat perbedaan } \\
\text { yang signifikan) }\end{array}$ \\
\hline
\end{tabular}

Data hasil penelitian ini sebelum di uji hipotesis, dilakukan terlebih dahulu uji prasyarat sampel terhadap data pretest dan posttest dari kelas eksperimen dan kelas kontrol. Hasil yang diperoleh, yaitu data tersebut berdistribusi normal dan homogen. Hal ini menunjukkan bahwa sampel yang diambil memiliki keadaan awal yang sama.

Selanjutnya, untuk mengetahui apakah model discovery learning berbantuan multimedia interaktif berpengaruh atau tidak terhadap kemampuan berpikir kritis siswa, maka dilakukan uji hipotesis. Hasil dari uji hipotesis pretest menunjukkan $\mathrm{H}_{0}$ diterima, dapat diartikan bahwa antar kelas eksperimen dengan kelas kontrol tidak terdapat perbedaan kemampuan berpikir kritis siswa.

Berdasarkan hasil dari uji hipotesis data posttest menunjukkan $\mathrm{H}_{0}$ ditolak dan $\mathrm{H}_{1}$ diterima, sehingga dapat diartikan bahwa terdapat perbedaan rata-rata kemampuan berpikir kritis siswa pada kelas eksperimen dan kelas kontrol. Hal tersebut berarti terdapat pengaruh model discovery learning berbantuan multimedia interaktif terhadap kemampuan berpikir kritis.

Model discovery learning berbantuan multimedia interaktif terhadap kemampuan berpikir kritis tersebut, terlihat dari perbedaan persentase ratarata indikator berpikir kritis pada posttest kelas eksperimen yaitu sebesar 82,8\% dengan kategori sangat baik dan kelas kontrol hanya $73,3 \%$ dengan kategori baik. Persentase yang lebih besar yang diperoleh kelas eksperimen ini menunjukan bahwa model discovery learning berbantuan multimedia interaktif lebih efektif dibandingkan pembelajaran menggunakan metode konvensional.

Dalam proses pembelajaran, adanya media sangat berpengaruh sebab memiliki peranan besar yang mempengaruhi pencapaian tujuan pembelajaran media pembelajaran adalah suatu bagian penting dari proses pendidikan di sekolah karena itu menjadi suatu bidang yang harus dikuasai oleh setiap guru professional (Hamalik, 2003).

Media adalah segalah sesuatu yang dapat di gunakan untuk menyalurkan pesan dari pengirim ke penerima sehingga dapat merangsang pikiran, perasaan, dan minat serta perhatian siswa sedemikian rupa sehingga proses belajar terjadi (Sadiman, dkk., 2006)

Media sebagai komponen strategi pembelajaran merupakan wadah dari pesan yang oleh sumber atau penyalurannya ingin di teruskan kepada sasaran atau penerima pesan tersebut, dan materi di sampaikan adalah pesan pembelajaran, dan bahwa tujuan yang ingin dicapai adalah terjadinya proses belajar (Trianto, 2010). Pemilihan dan penggunaan media yang tepat dalam pembelajaran harus memperhatikan karakteristik siswa (Rusman, 2012).

\section{KESIMPULAN}

Berdasarkan hasil penelitian yang telah dilakukan, dapat disimpulkan bahwa terdapat pengaruh model discovery learning berbantuan multimedia interaktif terhadap kemampuan berpikir kritis siswa di SMPN 2 Poigar.

\section{DAFTAR PUSTAKA}

Adeyemi, S. B. (2012). Developing Critical Thinking Skills in Students: A Mandate for Higher Education in Nigeria. European Journal of Educational Research, 1(2), 155-161.

Agoestanto, A., \& Sukestiyarno, Y. L. (2017, April). Analysis of Mathematics Critical Thinking Students in Junior High School Based on Cognitive Style. 
In Journal of Physics Conference Series, 824(1), 012052.

Guntur, Eka A. \& Titin. (2014). Efektivitas Metode Guided Discovery Terhadap Hasil Belajar Pada Materi Plantae di SMAN 9 Pontianak. Jurnal Pendidikan dan Pembelajaran Khatulistiwa, 4(1).

Hamalik, O. (2003). Proses Belajar Mengajar. Jakarta: Bumi Aksara.

Hosnan. (2014). Pendekatan Scientific dan Kontekstual Pembelajaran Abad 21. Bogor: Ghalia Indonesia.

Hudha, M. N., \& Batlolona, J. R. (2017). How are the Physics Critical Thinking Skills of the Students Taught by Using Inquiry-Discovery Through Empirical and Theorethical Overview?. Eurasia Journal of Mathematics, Science and Technology Education, 14(2), 691-697.

Paat, M., Sutopo, H., \& Siregar, N. (2019, December). Developing a Mobile Multimedia-Based Learning Resource on Living of Komodo Dragons. In Proceedings of the 2019 3rd International Conference on Computer Science and Artificial Intelligence (pp. 273-277).

Riadi, E. (2016). Statstik Penelitian (Analisis Manual dan IBM SPSS). Yogyakarta: Andi Offset.

Riduwan. (2015). Belajar Mudah Penelitian. Bandung: Alfabeta.

Rusman. (2012). Model-Model Pembelajaran. Depok: Rajagrafindo Persada.

Sadia, I. W. (2014). Model-Model Pembelajaran Sains Konstruktivistik. Yogyakarta: Graha Ilmu.

Sadiman, A. S., dkk. (2006). Media Pendidikan Pengertian, Pengembangan dan Pemanfaatannya. Jakarta: Raja Grafindo.

Siregar, N., Sutopo, H., \& Paat, M. (2019). Mobile Multimedia-based Batakologi Learning Model Development. Journal of Mobile Multimedia, 15(4), 271-288.

Siregar, S. (2013). Statistik Parametrik Untuk Penelitian Kuantitatif. Jakarta: Bumi Aksara.

Slameto. (2010). Belajar dan FaktorFaktor yang Mempengaruhinya. Jakarta: Rineka Cipta.
Sugiyono. (2015). Metode Penelitian Combinasi. Bandung: Alfabeta.

Trianto. (2010). Model Pembelajaran Terpadu A. Surabaya: Bumi Aksara. 